\title{
Rhamphicarpa fistulosa, a widespread facultative hemi-parasitic weed, threatening rice production in Africa
}

\author{
J RODENBURG*, J J MORAWETZ $\dagger \&$ L BASTIAANS \\ *East and Southern Africa, Africa Rice Center, Dar es Salaam, Tanzania, †Rancho Santa Ana Botanic Garden, Claremont, CA, USA, and \\ $\ddagger$ Crop and Weed Ecology Group, Centre for Crop Systems Analysis, Wageningen University, Wageningen, The Netherlands
}

\section{Summary}

Rhamphicarpa fistulosa is a facultative hemi-parasitic plant of the Orobanchaceae family, adapted to wet soils. Apart from tropical Australia, it is only found in sub-Saharan Africa, where it is considered a minor weed in cereal crops such as rice. Due to this status, the species has received only sporadic attention. Recent field observations and encounters with rice farmers in several African countries showed that $R$. fistulosa is, however, a more serious and increasing production constraint than previously thought. Results from a systematic literature review and a global herbarium study support this. The species has a broad distribution over Africa (at least 35 countries from Madagascar to Senegal and from Sudan to South Africa) and a wide range in altitude (0$2150 \mathrm{~m}$ a.s.1.) and environment (waterlogged swamps to moist free-draining uplands). Rhamphicarpa fistulosa is relatively independent and persistent because of the presumably wide host range, the facultative nature of its parasitism and its prolific seed (estimated 100000 seeds $\mathrm{m}^{-2}$ under moderate infestation levels). Finally, R. fistulosa causes severe yield losses (average 60\%) and high regional annual economic losses (estimated US \$175 million), while effective control options are scant and awareness of the species among important R\&D stakeholders is almost absent. An integrated approach is advocated to assist the rice sector to reduce current $R$. fistulosa-inflicted losses and to prevent further spread of the species into new areas.

Keywords: rice vampire weed, inland valley, rain-fed lowland, parasitic plant, integrated weed management, subsistence farming, sub-Saharan Africa.

\section{Introduction}

Rhamphicarpa fistulosa (Hochst.) Benth. (Orobanchaceae) is an annual, facultative hemi-parasitic forb species (Hansen, 1975; Ouédraogo et al., 1999). Although much less well known than other weedy members of Orobanchaceae, such as Striga Lour. spp., Orobanche L. spp. and Phelipanche Pomel spp., it is a widespread and common feature in the natural vegetation of ephemeral wetlands (e.g. Hansen, 1975; Cissé et al., 1996; Deil, 2005; Müller \& Deil, 2005; Müller, 2007), as well as in agro-ecosystems of tropical Africa, including cropping systems characterised by dryer soils (Ouédraogo et al., 1999; Gworgwor et al., 2001; Rodenburg et al., 2011). The species is increasingly encountered and perceived as a noxious weed in rice. 
Rice farmers and agricultural extension agents lack knowledge on effective management strategies for this species. This is mainly a result of the low awareness of its existence and consequently the low priority it has so far received for research and development (Schut et al., 2014). Indeed, many knowledge gaps exist with respect to $R$. fistulosa. There is an urgent need to understand just how important the species is in terms of its distribution, invasiveness and agronomic and economic impacts. Secondly, effective management strategies should be developed that prevent the species' spread and reduce crop damage. Knowing the ecological and biological characteristics of the plant is of utmost importance for the development of such strategies. While researchers, mainly botanists, have studied and reported on R. fistulosa since 1835, when it was first described and named, the information is scattered and far from complete. A structured and co-ordinated approach is advocated to complete the missing information and increase our understanding of this species. To this end, we have reviewed all publicly available publications and herbarium specimens of this species. The objectives were to provide an overview of the current knowledge and understanding of the species' distribution, biology, ecology, invasiveness, agronomic and economic importance and management and to identify and prioritise research questions. The overall aim of this review was to alert decision and policy makers and stakeholders of the emerging problem caused by $R$. fistulosa and to prioritise and guide research and development efforts aimed (i) at the control of this species where it has already turned into a weed and (ii) at the prevention of spread into new areas.

\section{What do we know about the plant species R. fistulosa?}

\section{Taxonomy, nomenclature and similarities to other species}

Rhamphicarpa fistulosa is an angiosperm species of the Lamiales order, Orobanchaceae family (formerly Scrophulariaceae; Olmstead et al., 2001) and the genus Rhamphicarpa (Bentham, 1835; Hochstetter, 1841; Bentham, 1846; Engler, 1895; Hansen, 1975; Philcox, 1990; Mielcarek, 1996; Fischer, 2004; Table 1). Its phylogenetic position is not yet completely confirmed, but the species $R$. fistulosa has been placed under the tropical clade of Orobanchaceae previously reported by Morawetz et al. (2010), with Fischer et al. (2012) showing its closest relatives being the genera Sieversandreas Eb. Fisch., Bardotia Eb. Fisch. Schäferh. \& Kai Müll. and Randamaea Benth. The species R. fistulosa has a num- ber of local names in many of the countries where it occurs as a weed in rice (see Table 1). Based on the species' parasitic nature and the most common host crop species, rice vampire weed is proposed as the common name of $R$. fistulosa.

Plants are erect and slender, simple-stemmed and (mostly) glabrous, with smooth needle-like pale green leaves, in opposite arrangement (Fig. 1A and B), and can reach up to $120 \mathrm{~cm}$ height, depending on locality (Philcox, 1990). The species is adapted to semi-aquatic environments, with large (air) spaces between the cortical cells of the root aerenchyma to facilitate air flow under submerged conditions (Neumann et al., 1997; Ouédraogo et al., 1999).

Mature plants are branched and may turn reddish (Fig. 1C). Flowers are white, cream, pale pink or pale blue (the white form is most common in Africa) (Fig. 1D) with long tubes $(25-30 \mathrm{~mm})$ that are straight or slightly curved (Hansen, 1975; Fig. 1A and D). The fruits are asymmetrical and neatly beaked (Fig. 1A and B), about the size of a small pea, that is $6-15 \mathrm{~mm}$ long and 4-7 mm broad, containing 100-250 dark brown seeds. Seeds are oval shaped, $0.2 \times 0.55 \mathrm{~mm}$, and the outer seed coat forms a reticulate network covered by prominent ridges (Fig. 1A; e.g. Mielcarek, 1996; Ouédraogo et al., 1999) and weigh about $0.011 \mathrm{mg}$ (Rodenburg et al., 2011). For complete botanical descriptions, see Hansen (1975) and Ouédraogo et al. (1999).

Bentham (1835) was the first to describe a species within this genus, that is Rhamphicarpa longiflora Benth. Independently from this work, Hochstetter (1841) named the genus Macrosiphon and described two African species, M. fistulosus Hochst. and M. elongatus Hochst. These are currently considered synonyms of Rhamphicarpa fistulosa and $R$. elongata (Hochst.) O.J. Hansen respectively (Hansen, 1975). In total, 41 different names of species and subspecies (or varieties) have been given to plants presumed to belong to Rhamphicarpa, but many of them are no longer accepted. For instance, Hooker (1884) and van Steenis (1970) considered the African, Australian and Indian species to be different. The Australian plants were named $R$. australiensis Steen., but as van Steenis did not compare this species to the African or Caucasian species, this name was not widely acknowledged. In the literature prior to Staner's (1938) revision, many species that are currently considered to be part of the genus Cycnium were classified as Rhamphicarpa; For example, the hemi-parasitic Cycnium veronicifolium (Vatke) Engl. used to be called Rhamphicarpa veronicifolia Vatke (Fuggles-Couchman, 1935; Parker \& Riches, 1993). The closely related genera Rhamphicarpa and Cycnium are distinguished based on the form of 
Table 1 Taxonomy, scientific, common and local names of Rhamphicarpa fistulosa

\begin{tabular}{|c|c|c|}
\hline Scientific name & \multicolumn{2}{|l|}{ Rhamphicarpa fistulosa } \\
\hline Authors & \multicolumn{2}{|c|}{ Hochstetter (1841), Bentham $(1835,1846)$, Engler (1895) } \\
\hline Common name & \multicolumn{2}{|l|}{ Rice vampire weed } \\
\hline Family & \multicolumn{2}{|c|}{ Orobanchaceae (formerly: Scrophulariaceae) } \\
\hline Tribe & \multicolumn{2}{|l|}{ Buchnereae (formerly Gerardieae) } \\
\hline Order & \multicolumn{2}{|l|}{ Lamiales } \\
\hline Class & \multicolumn{2}{|l|}{ Angiospermae - Dicotyledons } \\
\hline Synonyms & \multicolumn{2}{|l|}{ Macrosiphon elongatus Hochst. } \\
\hline & \multicolumn{2}{|c|}{$\begin{array}{l}\text { Rhamphicarpa longiflora (Indian species most related to } R \text {. fistulosa) Benth. } \\
\text { Macrosiphon fistulosus (synonym of } R \text {. longiflora) Hochst. } \\
\text { Rhamphicarpa australiensis Steenis }\end{array}$} \\
\hline \multirow{10}{*}{$\begin{array}{l}\text { Vernacular } \\
\text { names }\end{array}$} & Tutari (R. longiflora) & - India - Maharashtra state (Marathi) \\
\hline & $\begin{array}{l}\text { Grassland trumpet or trumpet flower } \\
\text { (R. longiflora) }\end{array}$ & - India (English) \\
\hline & Kayongo & - Uganda - Namutumba District (Lusoga) \\
\hline & Otcha, Do, Corico, Efri & - Benin - Dassa, Glazoué Districts (Idaatcha) \\
\hline & Mbosyo & - Tanzania - Kyela District (Nyakusa) \\
\hline & Ntengo ya nchele nchele & - Tanzania - Mbinga District (Nyasa) \\
\hline & Mulungi & - Tanzania - Ifakara (Kisajala) \\
\hline & Angamay & - Madagascar - Mid West (Malagasy) \\
\hline & Mogogatau & - Zambia - North (Tswana) \\
\hline & Loho Soukoh/Soukoh lô & $\begin{array}{l}\text { - Cote d'Ivoire - North: Korhogo/Boundiali (Dioula/ } \\
\text { Senoufo) }\end{array}$ \\
\hline
\end{tabular}

Sources: Hochstetter (1841), Bentham (1835, 1846), Engler (1895), von Wettstein (1891), Steenis (1970), Hansen (1975), Ouédraogo et al. (1999), l'Herbier de Parc Botanique et Zoologique de Tsimbazaza, Antananarivo, Madagascar, Herbarium of the Department of Botany, University of Dar es Salaam, Muséum National d'Histoire Naturelle, Paris, France (SONNERAT).

the capsules and the presence of a beak on their capsules; that is, oblique ovoid capsules with beaks (Rhamphicarpa) compared with straight oblong capsules without a beak (Cycnium) (Staner, 1938). In fact, the genus name Rhamphicarpa is a combination from the Greek words for 'beak' or 'bill' and 'fruit'. Another distinctive feature is the stamen structure; that is stamens arising at two levels in the corolla tube with the style never exceeding the lower pair of stamens (Cycnium) compared with stamens equal in length with the style exceeding the stamens (Rhamphicarpa) (Philcox, 1990; Fischer, 1999; Leistner, 2005). Rhamphicarpa fistulosa can be confounded with Cycnium recurvum (Oliv.) Engl. (previously named Rhamphicarpa recurva Oliv. and $R$. tenuisecta Standl.), which has a similar appearance and overlapping distribution in parts of north-east and south-east Africa. However, the tube of the corolla of C. recurvum is about a third of that of $R$. fistulosa. Moreover, C. recurvum has a distinctly different habitat, favouring dry conditions (Mielcarek, 1996). There is, however, still no conclusive evidence that Cycnium and Rhamphicarpa are really separate genera. A recent molecular phylogenetic study, the first of this type to include Rhamphicarpa, seems to indicate a much closer lineage with the Madagascan genera Radamaea/Sieversandreas than with Cycnium (Fischer et al., 2012). Further phylogenetic work will be necessary to definitively determine the closest relatives of Rhamphicarpa.

There are five other species accepted within Rhamphicarpa: R. longiflora Wight ex. Benth., R. elongata (Hochst) O.J. Hansen, R. brevipedicellata O.J. Hansen, $R$. capillacea A. Raynal and $R$. medwedewii Albov. The latter species is only found in the Caucasus. The species $R$. fistulosa is most often confused with $R$. longiflora, but they differ in distribution; that is, R. longiflora is only found in India. These two species can be distinguished by the form of the beak of their capsules: $R$. fistulosa has a straight beak, while the Indian $R$. longiflora has an oblique beak (Bentham, 1846). Hansen (1975) concluded that $R$. fistulosa is the correct name for the species occurring in New Guinea, Australia, Madagascar and Africa, while $R$. longiflora is the Indian species of this genus. This is still the currently accepted taxonomic division (Philcox, 1990; Mielcarek, 1996).

In Central Africa, R. fistulosa can be confounded with $R$. capillacea, which also has long white flowers and favours similar growth conditions (Raynal, 1970). Rhamphicarpa capillacea can be distinguished from the other Rhamphicarpa species by the leaves (entire for $R$. capillacea compared with pinnatisect for the others) and capsules (isodiametric for $R$. capillacea compared with variable and never isodiametric for the others) (Raynal, 1970; Hansen, 1975). 
Fig. 1 (A) Drawing of Rhamphicarpa fistulosa, adapted from Hansen (1975), showing habit (a), flower (b), capsule (c) and seed (d); (B) R. fistulosa seed capsules, (C) close-up of the flower head with flowers and capsules at different stages and with reddish stem; (D) R. fistulosa flower during daytime. Photographs were taken by J Rodenburg.

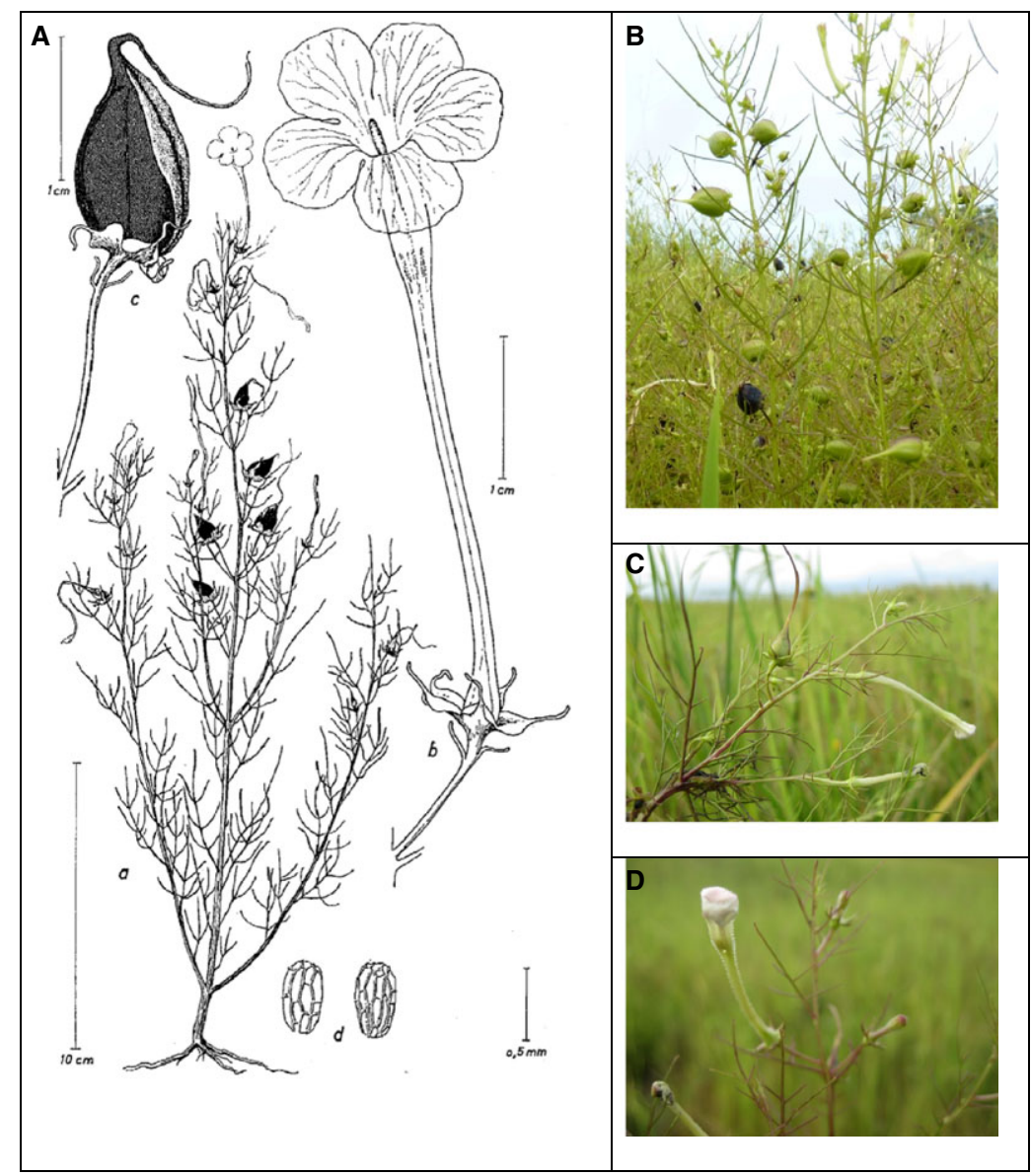

Finally, R. fistulosa can be confounded with the Striga spp. that have an overlapping host range (mainly Striga hermonthica (Delile) Benth., S. asiatica (L.) Kuntze or S. aspera (Willd.) Benth.). The morphological differences between the species are obvious (e.g. Parker \& Riches, 1993), but due to their parasitic nature and similarities in host crop ranges and geographic distribution, local names given by farmers are often the same for R. fistulosa and Striga spp. (e.g. 'Kayongo' in Uganda, 'Otcha' and 'Do' in Benin; Table 1). Rhamphicarpa fistulosa is sometimes even referred to as 'the Striga of rice', even though both R. fistulosa and Striga spp. parasitise rice. An important difference is that Striga spp. are usually found on rice grown in the free-draining uplands, whereas $R$. fistulosa mainly parasitises rice in the water-logged lowlands and hydromorphic zones, sometimes within the same upland-lowland continuum (Kabiri et al., 2015).

\section{A facultative root hemi-parasite}

Rhamphicarpa fistulosa roots develop haustoria like other parasitic plants such as Striga spp. and Orobanche spp. (Parker \& Riches, 1993; Press \& Graves, 1995). While Striga species develop terminal and lateral haustoria, R. fistulosa, like other facultative parasites such as Rhinanthus minor L. (Seel et al., 1993; Cameron \& Seel, 2007) and Buchnera hispida Buch.-Ham. Ex. D. Don, (e.g. Neumann et al., 1997, 1999), only develops lateral haustoria that bridge the parasite and host root xylem (Kuijt, 1969; Neumann et al., 1998, 1999). About three to four weeks after sowing of the host plant, upon contact between the parasite and the host root, the parasite starts to develop haustoria. The haustorium initiation starts with the development of tiny hairs around the area of outgrowth, which sometimes facilitate the attachment of the parasite with the host root (Neumann et al., 1998). If the host root and the parasite root are parallel to each other, the parasite root can develop multiple haustoria. Without a host in its vicinity, the parasite does not develop any haustoria, indicating that some morphogenic host root factors are involved in the host detection of the parasite. Upon establishment of a xylem-to-xylem connection, the parasite can extract host metabolites, nutrients and water from its host (e.g. Aly, 2013). In some cases, phenolic substances or lignins can be observed on the host roots where the parasite attempts to penetrate, indicating the existence of a host plant defence reaction (Neumann 
et al., 1999). Rhamphicarpa fistulosa uses the $\mathrm{C}_{3}$ pathway for $\mathrm{CO}_{2}$ assimilation (Press et al., 1987), but plants are pale green (both stem and leaves), which suggests a low chlorophyll content and consequently suboptimal $\mathrm{CO}_{2}$ assimilation levels, explaining the species' need for host metabolites. The biomass accumulated by a parasitising $R$. fistulosa plant is usually much smaller than the biomass lost by the affected host plant (Rodenburg et al., 2011). This would point to a phytotoxic mechanism, but the existence of such a pathological effect is not yet confirmed (Rodenburg et al., 2010).

The host range of $R$. fistulosa has not yet been fully established. Apart from cereal crops such as maize, millet and rice (Bouriquet, 1933; Kuijt, 1969; Cissé et al., 1996; Ouédraogo et al., 1999), it has been reported to parasitise groundnut (Arachis hypogaea L.; Bouriquet, 1933) and cowpea (Vigna unguiculata (L.) Walp.), although the latter report concerned $R$. veronicifolia Vatke (= Cycnium veronicifolium (Vatke) Engl.) rather than $R$. fistulosa (Fuggles-Couchman, 1935). Supposedly it can also parasitise wild grasses (Poaceae) and members of the Cyperaceae, Leguminosae and Labiatae families (Bouriquet, 1933). Although other facultative hemi-parasites such as Rhinanthus minor are able to parasitise both grasses and legumes (Cameron \& Seel, 2007), parasitic plant species typically parasitise either monocotyledons or dicotyledons; hence, these reports need to be confirmed.

\section{Reproduction and seed biology}

Flowers are white and fragrant, only open at dusk and usually last only one night, after which they fall off (Cissé et al., 1996). Plants growing without a host develop fewer flowers (often just one or very few) than plants having successfully established a parasitic relationship with a suitable host (Ouédraogo et al., 1999). The reproductive biology of $R$. fistulosa is unclear. Some reports mention cross-pollination by night moths (Parker \& Riches, 1993; Cissé et al., 1996; Ouédraogo et al., 1999), perhaps mainly due to the shape of the corolla that is compatible with hawk-moth pollination (e.g. Fischer et al., 2012) and the fact that the flowers only open between sunset and sunrise. However, viable seeds have been produced in the absence of such insects in controlled screen house environments (A van Ast, pers. comm.). The species may produce well over 1000 small seeds per plant. As densities above 100 plants per $\mathrm{m}^{2}$ are not unusual (N'cho et al., 2014), seed production may easily exceed 100000 seeds per $\mathrm{m}^{2}$.

Little is known about seed longevity under natural conditions, but according to Gbèhounou and Assigbé (2004), seeds are short-lived (approximately 1 year). Seeds of $R$. fistulosa have a dormancy period of six months and require water and daylight for germination (Ouédraogo et al., 1999). Contrary to other parasitic Orobanchaceae, seeds of $R$. fistulosa do not require pre-conditioning for germination (A van Ast, pers. comm.). Moreover, in contrast to obligate parasitic plants (e.g. Striga spp.), the seeds of the facultative hemi-parasitic $R$. fistulosa do not need a host-derived stimulant for germination (Ouédraogo et al., 1999; Gbèhounou \& Assigbé, 2004). Germination occurs within about 4 days, when the conditions are favourable. Two to three days after germination, the green cotyledons emerge, after which the seedling starts to develop leaves. Rhamphicarpa fistulosa usually has a low initial growth rate (J Rodenburg, pers. obs.).

Flowering and maturity times seem to vary with growing conditions. Ouédraogo et al. (1999) reported initiation of flowering around 140 days after sowing (DAS) in trials in Burkina Faso, but an earlier onset of flowering (around 70-100 DAS) has been observed in trials in Benin and Tanzania ( $\mathrm{J}$ Rodenburg, pers. obs.). Plants of $R$. fistulosa can continue growth and reproduction beyond the harvest of the crop, provided that there is enough residual soil moisture.

\section{Where and under what conditions can we find $R$. fistulosa?}

\section{Biotic and abiotic environment}

Rhamphicarpa fistulosa thrives in wet and semi-aquatic environments in forest and savannah zones (e.g. Cissé et al., 1996). It can grow in peaty soils over rock substratum, on or between rocks in shallow, slow running streams, but more frequently in grassy swamps, temporary or permanently flooded areas such as inland valley swamps and poorly drained rain-fed lowland rice fields (Hansen, 1975; Philcox, 1990; Ouédraogo et al., 1999). In areas where rice, the most common host of $R$. fistulosa, is grown along the upland-lowland continuum, the weed is only found in the lower, seasonally flooded zones (Kabiri et al., 2015), although recently, we have observed it on higher parts as well (J Rodenburg, pers. obs.). Soils favouring $R$. fistulosa are generally poor in $\mathrm{N}, \mathrm{P}$ and $\mathrm{K}$ with relatively high silt content (Ouédraogo et al., 1999; Kabiri et al., 2015), which would imply a high degree of salinity tolerance. The exact range of salinity tolerated needs to be confirmed.

Fungi (i.e. Fusarium spp., Sclerotium rolfsii) and bacteria (i.e. Stenotrophomonas maltophilia, Bacillus pumilus, B. megaterium) have been observed as pathogenic to R. fistulosa (Sikirou et al., 2002a). The species is also attacked by beetles and caterpillars. The Nymphalid caterpillar Junonia spp. has frequently been 
observed on $R$. fistulosa plants and is able to feed on all the above-ground plant tissue (J Rodenburg, pers. obs.). The Coleoptera (beetle) Smicronyx spp. (Curculionidae) has also been observed to cause foliar damage to $R$. fistulosa plants and to lay eggs in the seed capsules (Sikirou et al., 2002a). The larvae of these beetles feed on the immature seeds in the capsule and make the capsule look swollen (J Rodenburg, pers. obs.).

Rhamphicarpa fistulosa has been observed to co-occur with other parasitic weeds, such as Alectra vogelii Benth., Striga asiatica, S. aspera and S. hermonthica in Guinea (Cissé et al., 1996), Striga aspera in Burkina Faso (Sallé et al., 1994), Striga asiatica in Tanzania (Johnson et al., 1998; Kayeke et al., 2010; Kabiri et al., 2015) and Madagascar (M Cissoko \& A P Andrianaivo, pers. comm.), and $S$. hermonthica in Mali, Burkina Faso (Sallé et al., 1994) and Uganda (J Rodenburg, pers. obs.). Rhamphicarpa fistulosa is, however, rarely observed with any of these species in the same crop, due to its distinct environmental niche (Kabiri et al., 2015).

The species has been indicated as characteristic of the West African class of mud vegetation: Rhamphicarpo fistulosae-Hygrophiletea senegalensis (Deil, 2005; Müller \& Deil, 2005). Observed associated wild plant or weed species are: Parahyparrhenia annua (Hack.) W. D. Clayton, Sacciolepis microcorra Mez., Panicum spp. or wild rice (Oryza spp.) in Senegal, Burkina Faso and Mali (Ouédraogo et al., 1999) and Ammania auriculata Willd., Oryza longistaminata A. Chev. \& Roehr., Scleria vogelii C. B. Clarke, Fimbristylis littoralis Gaudich. and Mariscus longibracteatus Cherm. in a field survey in southern Tanzania (Kabiri et al., 2015). Whether or not any of these plants are also parasitised by $R$. fistulosa is not known.

\section{Geographic distribution}

The genus Rhamphicarpa is spread over four subareas: (i) sub-Saharan Africa and Madagascar, (ii) India, (iii) New Guinea and tropical Australia and (iv) the Caucasus. It is not clear yet how the genus could have spread to such discontinuous and remote places. It was hypothesised by Hansen (1975) that the genus Rhamphicarpa originated in Africa and that R. fistulosa represents the ancestral stock, as this species is the most widely distributed and the only taxon that is found in more than one subarea. From Africa, the genus may have spread to other areas, while subsequent environmental changes (e.g. in climate) may have caused a break-up of the original distribution to the currently observed discontinuous subareas.

Rhamphicarpa fistulosa is a very widespread species in tropical Africa (Staner, 1938; Müller, 2007). Combining a literature study with a search in national and international herbaria and our own field observations, we retrieved 392 observations, 378 of which can be traced back to geo-coordinates and 348 of which seemed to be unique individual observations/specimens. They are collected from 35 countries (Table 2), and the distribution of the species' observations is shown in Fig. 2. From two countries, the Gambia and Egypt, we only found a reference in the literature (i.e. Mielcarek, 1996), but no actual herbarium specimen or concrete observation with a name or geo-reference to the location. Liberia, Sierra Leone, Equatorial Guinea, Eritrea, Somalia and Comoros are the most remarkable absentees of the list of countries where $R$. fistulosa was observed, as these countries are located within the species' distribution zone. Apart from the possibility that this species does indeed not occur in these countries, the absence of any herbarium record may simply be a symptom of an incomplete national flora inventory or a weak national research infrastructure, which may be a result of recent turbulent histories, characterised by political instability and armed conflicts. The altitude of collections or observations ranged from 2 to $1750 \mathrm{~m}$ a.s.l. (average: $536 \mathrm{~m}$ ), the latitude ranged from -28.72 to 19.25 degrees, and the longitude ranged from -16.85 to 49.97 degrees (Fig. 2). Previously, $R$. fistulosa distribution in Africa was assumed to be restricted to sub-Saharan regions, below $17^{\circ} \mathrm{N}$, but our herbarium and literature search provided indications that the species can be found in more northern parts of Africa, as well. Outside Africa, it is reported in New Guinea and Australia (USDA, 2013), notably the northern tropical areas of Queensland (Martin, 2000).

\section{Means of spread}

Rhamphicarpa fistulosa seeds are minute and can adhere to crop seeds harvested from infested fields; if these seeds are then marketed, they can be introduced to previously uninfested fields when they are sown. Other likely means of introduction are through flood water, as $R$. fistulosa is mostly found along streams or in temporary flooded areas, and by wild or domesticated animals, for example free-roaming cattle in infested fields. The latter is a commonly observed a feature in the agricultural systems where R. fistulosa constitutes a weed problem (J Rodenburg, pers. obs.). Seeds are transported in the fur or hooves of the animals or ingested by animals feeding on crop residues at one place and deposited in their droppings in another place. Such means of dispersal is believed to be over relatively short distances, that is the typical distances these cattle cover. Although no published studies are available on seed dispersal for R. fistulosa, the above-mentioned processes have been reported as 
Table 2 Rain-fed rice area, yields, total production and Rhamphicarpa fistulosa-inflicted economic losses in African countries where $R$. fistulosa was reported, sorted in decreasing order of magnitude

\begin{tabular}{|c|c|c|c|c|c|}
\hline Country & $\begin{array}{l}\text { Total area } \\
\text { of rain-fed } \\
\text { lowlands rice } \\
\text { systems (ha)* }\end{array}$ & $\begin{array}{l}\text { Average estimated } \\
\text { yield from rain-fed } \\
\text { lowlands }\left(\mathrm{t} \mathrm{ha}^{-1}\right) \dagger\end{array}$ & $\begin{array}{l}\text { Estimated milled } \\
\text { rice production } \\
\text { from rain-fed } \\
\text { lowlands (tonnes) }\end{array}$ & $\begin{array}{l}\text { Estimated minimum } \\
\text { annual economic } \\
\text { loss caused by } \\
\text { R. fistulosa (US } \$ \text { ) }\end{array}$ & $\begin{array}{l}\text { Estimated maximum } \\
\text { annual economic } \\
\text { loss caused by } \\
R \text {. fistulosa (US } \$ \text { ) }\end{array}$ \\
\hline Nigeria & 1032935 & 3.02 & 1871678 & 17293049 & 123521778 \\
\hline Tanzania & 677806 & 1.89 & 768632 & 7101643 & 50726023 \\
\hline Madagascar & 322688 & 1.71 & 331078 & 3058937 & 21849551 \\
\hline Cote d'Ivoire & 314863 & 1.61 & 304158 & 2810212 & 20072945 \\
\hline Guinea & 381756 & 1.10 & 25195 & 2327931 & 16628082 \\
\hline Mali & 134851 & 2.85 & 230595 & 2130545 & 15218177 \\
\hline Ghana & 129533 & 1.16 & 90155 & 832971 & 5949795 \\
\hline Mozambique & 73954 & 1.89 & 83864 & 774845 & 5534611 \\
\hline Uganda & 72109 & 1.89 & 81772 & 755515 & 5396533 \\
\hline Burkina Faso & 61743 & 1.71 & 63348 & 585296 & 4180685 \\
\hline Guinea-Bissau & 47521 & 1.89 & 53889 & 497896 & 3556403 \\
\hline Chad & 37734 & 1.89 & 42790 & 395354 & 2823958 \\
\hline Cameroon & 19635 & 3.2 & 37699 & 348315 & 2487966 \\
\hline Senegal & 43948 & 1.22 & 32170 & 297229 & 2123061 \\
\hline Malawi & 28338 & 1.89 & 32135 & 296909 & 2120775 \\
\hline Togo & 27876 & 1.89 & 31611 & 292068 & 2086200 \\
\hline Benin & 23552 & 1.83 & 25860 & 238930 & 1706642 \\
\hline Gambia & 25231 & 1.28 & 19377 & 179034 & 1278816 \\
\hline DRC & 28021 & 0.88 & 14795 & 136697 & 976405 \\
\hline Zambia & 11775 & 1.89 & 13353 & 123371 & 881224 \\
\hline Burundi & 7778 & 1.89 & 8820 & 81493 & 582094 \\
\hline Angola & 6036 & 1.89 & 6845 & 63242 & 451726 \\
\hline Niger & 4727 & 1.89 & 5360 & 49527 & 353762 \\
\hline Ethiopia & 2811 & 1.89 & 3188 & 29452 & 210371 \\
\hline Sudan & 1438 & 1.89 & 1631 & 15066 & 107618 \\
\hline Congo & 1008 & 1.89 & 1143 & 10561 & 75437 \\
\hline CAR & 2731 & 0.53 & 868 & 8024 & 57314 \\
\hline South Africa & 572 & 1.89 & 649 & 5993 & 42808 \\
\hline Kenya & 414 & 1.29 & 320 & 2961 & 21147 \\
\hline Gabon & 258 & 1.89 & 293 & 2703 & 19308 \\
\hline Zimbabwe & 145 & 1.89 & 164 & 1519 & 10852 \\
\hline Total & 3523787 & 1.79 & 4410201 & 40747288 & 291052067 \\
\hline
\end{tabular}

*Estimates from Diagne et al. (2013a).

$\dagger$ Estimates for 18 countries derived from Diagne et al. (2013a); where national yield figures are not provided, the average yield from the 18 countries $\left(1.89 \mathrm{t} \mathrm{ha}^{-1}\right)$ was used.

$\ddagger$ trice area multiplied by paddy yield per area and a paddy to milled rice conversion factor of 0.6 .

\$Milled rice production multiplied by the estimated proportion of $R$. fistulosa-infested lowlands (22\%), the estimated proportion of infested fields in infested lowlands (72\%), the estimated minimum or maximum $R$. fistulosa-inflicted yield loss in these infested fields (14 and $100 \%$, respectively) and the most current world rice price (June 2014: US $\$ 416.64$ per tonne). Based on the average yield loss $(60 \%)$, the annual economic loss would be $\$ 175$ million.

possible contamination pathways for other parasitic weeds (Jacobsohn et al., 1987; Berner et al., 1994).

\section{What is the impact of $R$. fistulosa on rice in Africa?}

\section{Agronomic impact}

In north-eastern Nigeria (Adamawa, Borno, Jigawa, Bauchi, Gombe and Yobe states), R. fistulosa occurred in $48 \%$ of the 65 surveyed locations (each sampling area was $1 \mathrm{~km}^{2}$, comprising both farmland and natural vegetation) and was classified as 'abundant' (Gworgwor et al., 2001). In neighbouring Benin, an estimated $22 \%$ of the inland valleys where rice is grown were infested by $R$. fistulosa (Rodenburg et al., 2011), and in another survey in Benin, R. fistulosa was found in $72 \%$ of the rice fields in an infested inland valley (N'cho et al., 2014). When $R$. fistulosa invades a rice crop, resulting yield losses are generally high. The weed will parasitise the rice, removing metabolites, water and nutrients from it and presumably exerting a negative effect on its hormone regulatory system. The result is stunted growth of rice and reduced grain pro- 
Fig. 2 Distribution of Rhamphicarpa fistulosa in Africa, based on the literature (see References), national and international herbaria (see Acknowledgements) and field observations of the authors and co-workers. Locations where R. fistulosa has been observed or herbarium specimen have been collected are indicated by black dots; national paddy production (tonnes) estimates from rain-fed lowland rice (derived from area and yield figures provided by Diagne et al., 2013a), which may be impacted by $R$. fistulosa, are indicated by shading (see legend).

duction. In $R$. fistulosa-infested rice fields, yield losses can be as high as $100 \%$, as observed in Benin (Sikirou et al., 2002a; Gbèhounou \& Assigbé, 2003) and in Tanzania (Kayeke et al., 2010). The effect of R. fistul$o s a$ is also obvious from some of the local names it received from farmers, for example 'Efri' meaning 'killing' (Rodenburg et al., 2011), 'Otcha' referring to 'viper' (poisonous snake) and 'Do' meaning 'crop killer' (Table 1; Gbèhounou \& Assigbé, 2003). Pot experiments showed a range of $14-78 \% R$. fistulosainflicted grain losses, depending on rice variety and infestation level, while in infested fields in Benin, rice farmers estimated the average yield losses at $60 \%$ (Rodenburg et al., 2011). This average is much higher than estimated yield losses caused by non-parasitic weeds. For comparison, in a large survey held among rice farmers from 21 African countries, farmers growing rice in rain-fed lowlands who indicated weeds to be a problem, estimated weed-inflicted yield losses in rainfed lowland rice around $36 \%$, with a maximum average estimate of $43 \%$ in Kenya and $40 \%$ in Cote d'Ivoire (Diagne et al., 2013b).

\section{Economic impact}

Of the 35 countries where the species is found, at least 31 have rainfed lowland rice production systems, which, based on the most recent and accurate estimations (see Diagne et al., 2013a; data on Sudan and South Sudan are combined) annually produce about $7.35 \mathrm{M}$ tonnes of paddy $(4.41 \mathrm{M}$ tonnes of milled rice), worth around US $\$ 1.84$ billion. If $R$. fistulosa can be found in $22 \%$ of the rice grown inland valleys, and in $72 \%$ of the rice fields in such valleys, and given an average $R$. fistulosa-inflicted yield loss of $60 \%$ (ranging from $14 \%$ to $100 \%$ ), the current annual economic losses in sub-Saharan Africa are estimated at US $\$ 175$ million (with a range from US $\$ 41$ to 291 million; see Table 2). This is $9.5 \%$ of the total estimated value of the regional rain-fed lowland rice production. This estimate will become more accurate, once additional data are available.

\section{Social impact}

Infestation by $R$. fistulosa can be considered a poorman's problem. The parasitic weed is primarily problematic on marginal arable land, that is on low fertility and poorly drained soils, where water cannot be controlled (e.g. N'cho et al., 2014). These are the typical crop production conditions of resource-poor subsistence farmers, with a high proportion of female farmers (N'cho et al., 2014; Rodenburg et al., 2014). The weed has clear negative economic impacts and requires the farmer to invest valuable time for weeding (S. N'cho, pers. comm.). Weeding is often performed by 
women and children and consumes time that could otherwise be invested in family welfare and education (Ogwuike et al., 2014). Sometimes heavily infested fields are abandoned by the farmer (e.g. Rodenburg et al., 2011).

Little is known about the economic, social or environmental value of $R$. fistulosa. The species has been observed locally (in central Benin) being used as an insect repellent. Fresh plants were burned in a portable stove to produce smoke that was believed to repel (biting) insects such as mosquitoes (J. Rodenburg, pers. obs.). The plant was also reported to have medicinal uses in Machipi (near Ifakara), Kilombero District, Tanzania (EAH, 2013).

\section{How can we stop the future spread of $R$. fistulosa and reduce current damage?}

\section{Prevention}

As with other parasitic weeds of the Orobanchaceae family, the spread of $R$. fistulosa via their minute seeds can be prevented through basic phytosanitary measures. This means that any possible vectors that move seeds from an infested area should be controlled as much as possible (e.g. Rubiales et al., 2009; Goldwasser \& Rodenburg, 2013). Farm implements should be cleaned before using them in another field. Cattle movement between contaminated and clean fields should be avoided. Fields should be bunded to prevent seed movement from one field to another in water following uncontrolled floods and crop seeds should be cleaned before sowing. To prevent a seedbank build-up in a given field in a contaminated area, the crop should be regularly weeded (at least before flowering), so that weeds are removed from the field, both during the season and between seasons during any fallow period.

\section{Control}

The main weed management practices by rice farmers in Benin, Cote d'Ivoire and Tanzania with parasitic weed infested rice fields (including $R$. fistulosa and Striga spp.) are, in decreasing order of frequency: hand weeding, hand-hoe weeding, soil fertility management, herbicide use, water control, use of clean seeds, transplanting and the use of resistant or tolerant rice varieties (S. N'cho pers. comm.).

Rhamphicarpa fistulosa can be controlled with the post-emergence herbicide 2,4-D (Gbèhounou \& Assigbé, 2003). Fertiliser has a proven suppressive effect on $R$. fistulosa and a positive effect on rice yields of R. fistulosa-infected plants (Sikirou et al., 2002b; Rodenburg et al., 2011). Resource-poor rice farmers could use rice husks, which are often freely available, as it may reduce negative effects of $R$. fistulosa infestation on yield (Kayeke et al., 2013). Genetic variation in resistance and tolerance levels (Rodenburg et al., 2011), as well as in weed competitiveness (Rodenburg et al., 2009), was observed among adapted lowland rice cultivars, and these could be useful in $R$. fistulosainfested rice fields. For resource-poor farmers, the availability of improved rice varieties may, however, be limited. It is also hypothesised that improved water management, enabling either drainage or continuous flooding, can reduce $R$. fistulosa abundance (Parker \& Riches, 1993; Parker, 2012). Permanently flooded conditions, starting at the early stages of the crop, will contribute to reduced $R$. fistulosa plant numbers (van 't Klooster, 2011). Indeed, R. fistulosa has never been reported in irrigated rice systems where water is fully controlled. As R. fistulosa is particularly problematic in direct seeded rice (Johnson et al., 1998), transplanting is also likely to have a positive effect on rice performance in infested fields (Gbèhounou \& Assigbé, 2003). It will give the crop a time advantage over the weed, thereby rendering it more competitive. It has the additional advantage of facilitating hand weeding, the spot application of post-emergence herbicides or the use of a rotary weeder (e.g. Rodenburg \& Johnson, 2009). Timing of planting is also reported to be important (Langeloo, 2013; Rodenburg et al., 2013). However, whether or not early or late sowing is advantageous most probably depends on the local environmental conditions, in particular the hydrology and rainfall distribution. Exact relationships between environmental conditions, timing and parasitism should therefore be further investigated. An integrated management strategy against $R$. fistulosa, combining any of the above measures, is generally considered the most effective and sustainable solution (e.g. Sallé et al., 2000; Kayeke et al., 2010; Goldwasser \& Rodenburg, 2013).

\section{Discussion}

\section{Rhamphicarpa fistulosa: an increasing problem}

Rhamphicarpa fistulosa is a widespread and rather common species of natural wetland vegetation in Africa (e.g. Deil, 2005; Müller \& Deil, 2005; Müller, 2007). Sallé et al. (1994) observed the species to occur more frequently in natural vegetation than in crops. Indeed, for parasitic plants in general, the natural geographical range is usually much larger than their geographical range as a weed (Raynal Roques, 1994). This also seems to be the case for R. fistulosa. From the aforementioned herbarium study, many of the 
specimens were collected from national parks and nature reserves or otherwise uncultivated areas. From only $10 \%$ of the specimens or observations, we are sure that the plants were found in a rice field. We estimate that of the remaining $90 \%$ of specimens for which it was not indicated whether it was found in a rice crop, about $50 \%$ were collected from locations with at least a close vicinity to rice production sites and about $40 \%$ was likely not close to a rain-fed rice production area.

We hypothesise that when the natural habitats of $R$. fistulosa are turned into agricultural production sites, with a suitable host grown as a monoculture in a high density, the spontaneously occurring population of the species can rapidly increase, transforming the species into an agricultural pest (Bouriquet, 1933; , Akoegninou et al., 1999; Gbèhounou \& Assigbé, 2003). The only major staple crop that can be grown across the range of environments where $R$. fistulosa is observed, that is from hydromorphic to waterlogged soils, is rice. Rice is an increasingly important crop in sub-Saharan Africa. To keep pace with the increasing regional rice consumption, about 30 million tons more rice will be needed by 2035 (Seck et al., 2012). Part of the increase in production will likely come from expansion into areas previously unused for agriculture. Lowlying areas, such as inland valleys, with a relatively favourable hydrology and soil fertility, constitute highpotential areas for rice production and are likely to be increasingly exploited for that purpose (Rodenburg et al., 2014). Intensification of rice production in these ecosystems may be threatened by infestations of $R$. fistulosa (Johnson et al., 1998). Given its widespread distribution, the species is poised to become an even more serious parasitic weed throughout the continent.

We assume, based on the descriptions of its habitat (Hansen, 1975) and our own observations in the field, that $R$. fistulosa will in particular invade rain-fed lowland rice growing environments. However, the species was shown to have a relatively broad ecological niche (Kabiri et al., 2015), and we have recently observed it in the undulating landscape of Namutumba District (Ivukula village) in Uganda on the top of a hill in a free-draining upland rice field. In the same district, it has been found in maize fields as well. Ouédraogo et al. (1999) also reported this species in agro-ecosystems other than rain-fed lowlands. Hence, R. fistulosa seems to have a reasonably high degree of ecological plasticity.

Rhamphicarpa fistulosa remains a relatively unknown species among local extension and research (Schut et al., 2014) and therefore often goes unnoticed (as we observed in Benin, Cote d'Ivoire, Madagascar, Senegal, Tanzania and Uganda). The species is also easily overlooked because the flowers are only opening at sunset (Cissé et al., 1996). The actual extent of the problem of $R$. fistulosa in rain-fed lowland rice in subSaharan Africa is therefore expected to be largely underestimated. Recent observations in West Africa indicate the species is spreading. Rodenburg et al. (2011) observed an increase in the number of infested inland valleys growing rice over a period of about 10 years. In Cote d'Ivoire, farmers indicated an observed general increase of the species in the period 2008-2012 (S N'cho, pers. comm.). In Senegal in 2008, $R$. fistulosa was observed in a rice field in the Casamance, south of the Gambia (J Rodenburg, pers. obs.), where it had not been observed previously during annual surveys from 1985 to 1996 (Ouédraogo et al., 1999). For the farmer of the aforementioned highly infested upland rice field in Ivukula, Namutumba District, Uganda, $R$. fistulosa was a completely new species three years ago when he observed the first invasive individuals. Similarly in Madagascar (Tsiroanomandidy, Bongolava region), farmers indicated new infestations of $R$. fistulosa in their rice fields during recent years (M Cissoko and A P Andrianaivo, pers. comm.).

\section{Future research topics}

Since its description by Bentham in 1835, the taxonomy, biology, ecology and agronomic importance of Rhamphicarpa fistulosa has been only infrequently studied. The species therefore remains relatively unknown and many knowledge gaps still need to be filled. Increased awareness and knowledge is required for the development and implementation of control strategies to prevent the species from becoming a more important constraint to food production in sub-Saharan Africa. Ten important research topics are listed below:

Within the domain of invasive plant ecology and environmental studies, (i) the invasiveness of $R$. fistulosa needs to be studied to ascertain whether the distribution is increasing, stable or decreasing. Furthermore, (ii) the main distribution mechanisms and the history of the spread of the genus over the discontinuous subareas would need to be clarified. Related to that, (iii) the altitude and environmental plasticity need to be confirmed, as well as the soil chemical ranges of the $R$. fistulosa habitat, with special focus on salinity and acidity tolerances. These all seem to be important parameters to infer the likely spread of the species. Next, within the economic science domain, (iv) our best-bet economic loss estimate of US $\$ 175$ million per year should be revised using updated figures on $R$. fistulosa incidences and yield losses in rain-fed rice 
systems per country with local rice prices and using solid spatial and economic models. This is important for priority setting of research and developments efforts, as well as for raising awareness of the problem. Within the domain of taxonomy, plant physiology and crop sciences, (v) the host-parasite and damage mechanisms need to be elucidated, as it remains unclear whether this can purely be defined as a sink-source relation or whether $R$. fistulosa negatively affects the host plant hormone balance and through that, the host metabolism and growth, as with Striga spp. Another fundamental issue, (vi) the distinction between Cycnium and Rhamphicarpa, requires further study, probably using molecular analyses. Next, (vii) the parasitic nature, the biology and ecology of other species of the genus Cycnium and Rhamphicarpa should be investigated, as other species from these families could potentially emerge as important parasitic weeds as well, (viii) the host range of $R$. fistulosa (and other parasitic species of Rhamphicarpa and Cycnium) needs to be confirmed, as it will determine whether crop rotations, inter- or relay cropping are useful control methods, and which species should then be used. Related to that, (xi) feasible control strategies for rice farmers need to be further investigated and developed. In particular, the timing of crop and weeding operations and soil fertility management seems to be promising avenues to explore further. Another potentially interesting control option is the use of resistant or tolerant host crop varieties. To explore and use this option (x) the host resistance and tolerance mechanisms and responsible genes need to be identified and possibly transferred to adapted cultivars.

\section{Conclusions}

Rhamphicarpa fistulosa (rice vampire weed) is a widespread facultative hemi-parasitic weed, threatening rice production in Africa. Based on a literature and herbarium study, we conclude that $R$. fistulosa is an important rice production constraint in some areas, particularly in subsistence rice production systems, and poses a strong threat for rice production in other areas in Africa. The species has a broad distribution over tropical Africa, occurring in at least 35 countries geographically spread from eastern Madagascar to western Senegal and from Sudan to South Africa. In addition to the wide geographic range, $R$. fistulosa has been observed at widely varying altitudes, from sea level to an estimated $1750 \mathrm{~m}$ a.s.l., and under a range of ecological conditions, from waterlogged swamps to (moist) free-draining uplands. Combined with a presumably wide host range, the facultative nature of its parasitism and prolific seed production, the plant has a putative high degree of ecological plasticity. While the weed has very significant effects on rice productivity when present, farmers and even extension services are generally unaware of effective and affordable control options. Despite the wide distribution and severe economic consequences (an estimated annual loss of US $\$ 175$ million), awareness of the species among research, extension and development stakeholders is largely lacking.

A systematic and integrated approach is advocated to assist farmers and other stakeholders in affected areas to reduce current losses due to this parasitic weed and to prevent future spread into other areas. Important knowledge gaps concerning the species' taxonomy, biology, ecology, parasitic nature, invasiveness and economic impact need to be filled. This will enable informed development of effective integrated control and prevention strategies and form the necessary bedrock for increasing the awareness among a wider range of stakeholders and actors within research, development, education and policy domains.

\section{Acknowledgements}

The authors gratefully acknowledge the assistance of the following herbaria (and curators): Kew Royal Botanic Gardens (David J. Goyder); South African National Biodiversity Institute (Brenda Daly); Missouri Botanical Garden (George Schatz, Pete Lowry, James C. Solomon), MBG's TROPICOS database; Muséum National d'Histoire Naturelle (SONNERAT); l'Herbier de Parc Botanique et Zoologique de Tsimbazaza, Antananarivo, Madagascar (Solo Rapanarivo, Frank Rakotonasolo); l'Herbier du DBEV, Université d'Antananarivo (Cathy Madiomanana, Verohanitra Rafidison); National Herbarium of Rwanda (Minani Vedaste); Herbarium of the Department of Botany, University of Dar es Salaam (Frank Mbago); East African Herbarium, National Museums of Kenya (Itambo Barnabas Malombe); as well as technical assistance from Runyambo Irakiza, Derek Makokha, Mamadou Cissoko (AfricaRice) and Alain Paul Andrianaivo (FOFIFA). Sander Zwart and Justin Djagba (AfricaRice) are kindly acknowledged for their assistance in the production of the distribution map. We also thank Lytton John Musselman (Old Dominion University) for sharing valuable information with us and Aad van Ast (Wageningen University) for proofreading our manuscript. This study forms part of the PARASITE project, funded by the Integrated Programmes Scheme of the Netherlands Organisation for Scientific Research - Science for Global Development (NWO-WOTRO; grant number W 01.65.327.00). Additional support is provided by the CGIAR 
Research Program on Climate Change, Agriculture and Food Security (CCAFS) and the National Science Foundation (DEB1119801 to JJM).

\section{References}

Akoegninou A, Houndagba CJ, Kokou K \& Akpagana K (1999) Quelques aspects botaniques et écologiques de Rhamphicarpa fistulosa (Hochct.) Benth.

(Scrophulariaceae), plante adventice parasite du riz de basfonds au Bénin (Afrique de l'Ouest). Journal de Botanique de la Société Botanique de France 11, 75-81.

Aly R (2013) Trafficking of molecules between parasitic plants and their hosts. Weed Research 53, 231-241.

Bentham G (1835) Synopsis of the Buchnereae, a tribe of Scrophulariaceae. Companion to the Botanical Magazine 1, 356-384

Bentham G (1846) Ordo CXLII. Scrophulariaceae. In: Prodromus Systematis Naturalis Regni Vegetabilis, Vol. 10. (ed. A De Candolle), 186-586. Parisii: Sumptibus Sociorum Treuttel et Würtz,1824-73, Paris, France.

Berner DK, Cardwell KF, Faturoti BO, Ikie FO \& Williams OA (1994) Relative roles of wind, crop seeds, and cattle in dispersal of Striga spp. Plant Disease 78, 402-406.

Bouriquet G (1933) Une Scrophulariacée parasite du riz à Madagascar. Revue de Pathologie Végétale et D'Entomologie Agriculture de France 20, 149-151.

Cameron DD \& Seel WE (2007) Functional anatomy of haustoria formed by Rhinanthus minor: linking evidence from histology and isotope tracing. New Phytologist 174, 412-419.

Cissé J, Camara M, Berner DK, Musselman LJ (1996) Rhamphicarpa fistulosa (Scrophulariaceae) damages rice in Guinea. In: Advances in Parasitic Plant Research: 6th Parasitic Weeds Symposium (eds MT Moreno, JI Cubero \& DK Berner et al. ), 518-520. Advances in Parasitic Plant Research, Junta de Andalucia, Dirección General de Investigación Agraria, Cordoba, Spain.

Deil U (2005) A review on habitats, plant traits and vegetation of ephemeral wetlands - a global perspective. Phytocoenologia 35, 533-706.

Diagne A, Amovin-Assagba E, Futakuchi K \& Wopereis MCS (2013a) Estimation of cultivated area, number of farming households and yield for major rice-growing environments in Africa. In: Realizing Africa's Rice Promise (eds MCS Wopereis, DE Johnson, N Ahmadi, E Tollens \& A JALLOH), 35-45. CABI, Wallingford, Oxfordshire, UK.

Diagne A, Amovin-Assagba E, Futakuchi K \& Wopereis MCS (2013b) Farmers perceptions of the biophysical constraints to rice production in sub-Saharan Africa, and potential impact of research. In: Realizing Africa's Rice Promise (eds MCS Wopereis, DE Johnson, N Ahmadi, E Tollens \& A JALlOH), 46-68. CABI, Wallingford, Oxfordshire, UK.

EAH (2013) Rhamphicarpa Fistulosa (Hochst.) Benth. Herbarium Specimen at the East African Herbarium, Kenya. East African Herbarium, Nairobi, Kenya.

Engler A (1895) Die Pflantzenwelt Ost-Afrikas und der Nachbargebiete.
FISCher E (1999) Flore D'Afrique Centrale. Scrophulariaceae (Première Partie). The National Botanical Garden of Belgium, Meise, Belgium.

Fischer E (2004) Scrophulariaceae. In: Families and Genera of Vascular Plants (ed Klaus KubitzKi), Berlin: Springer.

Fischer E, Schaferhoff B \& Muller KF (2012) The new monotypic genus Bardotia (Orobanchaceae) from Madagascar and remarks on the phylogenetic relationships of the African and Madagascan genera Parastriga, Radamaea, Rhamphicarpa and Sieversandreas. Phytotaxa 46, 19-33.

Fuggles-Couchman NR (1935) A parasitic weed of sorghums (Rhamphicarpa veronicaefolio Vatke). The East African Agricultural Journal 1, 145-147.

Gbehounou G \& Assigbé P (2004) A study on germination of seeds of Rhamphicarpa fistulosa (Hochst.) Benth. a new pest of rice. 4th International Weed Science Conference, Durban, South Africa.

GbèHounou G \& Assigbé P (2003) Rhamphicarpa fistulosa (Hochst.) Benth. (Scrophulariaceae): new pest on lowland rice in Benin. Results of a survey and immediate control possibilities. Annales des Sciences Agronomique du Bénin 4, 89-103.

Goldwasser Y \& Rodenburg J (2013) Reducing the soil seed bank through cultural practices. In: Root Parasitic Orobanche - Parasitic Mechanisms and Control Strategies (eds DM Joel, J Gressel \& LJ Musselman), 393-414. Springer, Berlin Heidelberg, Germany.

Gworgwor NA, Ndahi WB \& Weber HC (2001) Parasitic weeds of North-eastern region of Nigeria: a new potential threat to crop production. The BCP conference, Farnham, England

Hansen OJ (1975) The genus Rhamphicarpa Benth. emend. Engl. (Scrophulariaceae). A taxonomic revision. Botanisk Tidsskrift 70, 103-125.

Hochstetter CHF (1841) Plantarum nubicarum nova genera. Flora 24, 369-384.

Hooker JD (1884) Scrophulariaceae. In: FLora of British India, Vol. 4. (ed JD Hooker), 246-319. Reeve, London, UK.

Jacobsohn R, Ben-Ghedalia D \& Marton K (1987) Effect of the animal's digestive system on the infectivity of Orobanche seeds. Weed Research 27, 87-90.

Johnson DE, Riches C, Camara M \& Mbwaga AM (1998) Rhamphicarpa fistulosa on rice in Africa. Haustorium: Parasitic Plants Newsletter 33, 2-3.

Kabiri S, Rodenburg J, Kayeke J et al. (2015) Can the parasitic weeds Striga asiatica and Rhamphicarpa fistulosa co-occur in rain-fed rice? Weed Research DOI: 10.1111 /wre. 12124 .

Kayeke J, Rodenburg J, Mwalyego F \& Mghogho R (2010) Incidence and severity of the facultative parasitic weed Rhamphicarpa fistulosa in lowland rainfed rice in southern Tanzania. 2nd Africa Rice Congress. Innovation and partnerships to realize Africa's rice potential, Cotonou, Benin.

Kayeke J, Rodenburg J, BastiaAns L et al. (2013) Locally adapted parasitic weed management strategies based on soil fertility amendments. 3rd Africa Rice Congress, Yaoundé, Cameroon. 
VAN 'T KLooster KJ (2011) Hydrological requirements of the facultative hemi-parasitic weed Rhamphicarpa fistulosa in rice. MSc-thesis, Wageningen University, Wageningen, the Netherlands.

Kuist J (1969) The Biology of Parasitic Flowering Plants. University of California Press, Berkeley, CA, USA.

LANGeloo D (2013) Reproductive success of parasitic weeds in rice production systems, affected by sowing date and host plant variety. MSc-thesis, Wageningen University, Wageningen, the Netherlands.

LeistNer OA (2005) Seed plants of southern tropical Africa: families and genera. 498 pp. SABONET Report No 26. ISBN 1-919976-07-8. http://www.sabonet.org.za/reports/ publications_report26.htm.

Martin HA (2000) Re-assignment of the affinities of the fossil pollen type Tricolpites trioblatus Mildenhall and Pocknall to Wilsonia (Convolvulaceae) and a reassessment of the ecological interpretations. Review of Palaeobotany and Palynology 111, 237-251.

MielcareK R (1996) The Scrophulariaceae in the flora of Central Africa (excl. Lindernieae). Fragmenta Floristica et Geobotanica 41, 3-248.

Morawetz JJ, Randle CP \& Wolfe AD (2010) Phylogenetic relationships within the tropical clade of Orobanchaceae. Taxon 59, 416-426.

MüLLER JV (2007) Herbaceous vegetation of seasonally wet habitats on inselbergs and lateritic crusts in West and Central Africa. Folia Geobotanica 42, 29-61.

Müller JV \& DeIl U (2005) The ephemeral vegetation of seasonal and semipermanent ponds in tropical West Africa. Phytocoenologia 35, 327-388.

N'cho S, Mourits M, Rodenburg J, Demont M \& Oude LANSINK A (2014) Determinants of parasitic weed infestation in rainfed lowland rice in Benin. Agricultural Systems 130, 105-115.

Neumann U, Pare J, Raynal Rogues A, Salle G \& Weber HC (1997) Characteristic trichomes and indumentum specialization in African and European parasitic Scrophulariaceae. Botanica Acta 110, $150-158$.

Neumann U, Sallé G \& Weber HC (1998) Development and structure of the haustorium of the parasite Rhamphicarpa fistulosa (Scrophulariaceae). Botanica Acta 111, 354-365.

Neumann U, Vian B, Weber HC \& Salle G (1999) Interface between haustoria of parasitic members of the Scrophulariaceae and their hosts: a histochemical and immunocytochemical approach. Protoplasma 207, 84-97.

Ogwuike P, Rodenburg J, Diagne A, Аgboh-Noameshie R \& Amovin-Assagba E (2014) Weed management in upland rice in sub-Saharan Africa: impact on labor and crop productivity. Food Security 6, 327-337.

Olmstead RG, DePamphilis CW, Wolfe AD, Young ND, Elisons WJ \& Reeves PA (2001) Disintegration of the Scrophulariaceae. American Journal of Botany 88, 348-361.

Ouédraogo O, Neumann U, Raynal Roques A, Sallé G, Tuquet C \& DembéLÉ B (1999) New insights concerning the ecology and the biology of Rhamphicarpa fistulosa (Scrophulariaceae). Weed Research 39, 159-169.
PArker C (2012) Parasitic weeds: a world challenge. Weed Science 60, 269-276.

Parker C \& Riches CR (1993) Parasitic Weeds of the World: Biology and Control. CABI, Wallingford, Oxon, England.

Philcox D (1990) Scrophulariaceae. Flora Zambesiaca 8 , $1-179$.

Press MC \& Graves JD (1995) Parasitic Plants. Chapman \& Hall, London, UK.

Press MC, Shah N, Tuohy JM \& Stewart GR (1987) Carbon isotope ratios demonstrate carbon flux from $\mathrm{C}_{4}$ host to $\mathrm{C}_{3}$ parasite. Plant Physiology 85, 1143-1145.

Raynal A (1970) Un nouveau Rhamphicarpa (Scrophulariaceae) d'Afrique Central. Adansonia 10, 329332.

Raynal Roques A (1994) Major, minor and potential parasitic weeds in semi-arid tropical Africa: the example of Scrophulariaceae. Biology and management of Orobanche, Proceedings of the Third International Workshop on Orobanche and related Striga research, Amsterdam, the Netherlands, 400-405.

Rodenburg J \& Johnson DE (2009) Weed management in rice-based cropping systems in Africa. Advances in Agronomy 103, 149-218.

Rodenburg J, Saito K, Kakai RG, Toure A, Mariko M \& KIEPE P (2009) Weed competitiveness of the lowland rice varieties of NERICA in the southern Guinea Savanna. Field Crops Research 114, 411-418.

Rodenburg J, Riches CR \& Kayeke JM (2010) Addressing current and future problems of parasitic weeds in rice. Crop Protection 29, 210-221.

Rodenburg J, Zossou-Kouderin N, Gbèhounou G et al. (2011) Rhamphicarpa fistulosa, a parasitic weed threatening rain-fed lowland rice production in sub-Saharan Africa - A case study from Benin. Crop Protection 30, 1306-1314.

Rodenburg J, Kayeke J, Bastianns L et al. (2013) Timing as a parasitic weed management strategy for smallholder rice farmers. 12th World Congress on Parasitic Plants, Sheffield, UK.

Rodenburg J, Zwart SJ, Narteh LT, Dogbe W, Kiepe P \& Wopereis MCS (2014) Sustainable rice production in African inland valleys: seizing regional potentials through local approaches. Agricultural Systems 123, 1-11.

Rubiales D, Fernandez-Aparicio M, Wegmann K \& Joel DM (2009) Revisiting strategies for reducing the seedbank of Orobanche and Phelipanche spp. Weed Research 49, 23-33.

Sallé G, Raynal Roques A, Tuquet C et al. (1994) Striga research in Mali, Burkina Faso and Senegal, supported by basic studies in France, in the framework of the STD2 project of the European Union. Biology and Management of Orobanche. Proceedings of the Third International Workshop on Orobanche and related Striga research, Amsterdam, the Netherlands, 700-709.

Sallé G, Tuquet C \& Neumann U (2000) Parasitic angiosperms: biology and methods of control. C.R. Académie Agricole de France 86, 59-67.

Schut M, Rodenburg J, Klerkx L, Kayeke J, van Ast A \& BastiaAns L (2014) RAAIS: Rapid Appraisal of Agricultural Innovation Systems (Part II). Integrated analysis of parasitic weed problems in rice in Tanzania. Agricultural Systems DOI: 10.1016/j.agsy.2014.09.004. 
Seck PA, Diagne A, Mohanty S \& Wopereis MCS (2012) Crops that feed the world 7: rice. Food Security 4, 7-24.

Seel We, Parsons AN \& Press MC (1993) Do inorganic solutes limit growth of the facultative hemiparasite Rhinanthus minor L. in the absence of a host. New Phytologist 124, 283-289.

Sikirou R, Gbehounou G \& Zannou A (2002a) Évaluation des pertes de rendement par Rhamphicarpa fistulosa et identification de ses microorganismes et ravageurs dans les périmètres rizicoles du Centre Bénin. Actes de l'Atelier Scientifique 1, Dassa, Bénin, 28-41.

Sikirou R, Gbehounou G, Zannou A \& Bouraima Y (2002b) Comportement variétal du riz fume a l'engrais minéral face au parasitisme de Rhamphicarpa fistulosa: lutte intégrée et efficacité économique. Actes de l'Atelier Scientifique 1, Dassa, Bénin, 42-60.

StAner P (1938) Revision des especes congolaises des genres Cycnium et Rhamphicarpa (Schrophulariacées). Bulletin du Jardin Botanique de L'état à Bruxelles 15, 147-151.

van Steenis C (1970) Miscellaneous notes on New Guinean plants IX. Blumea 10, 563-565.

USDA (2013) ARS, National Genetic Resources Program. Germplasm Resources Information Network - (GRIN). National Germplasm Resources Laboratory, Beltsville, MD, USA.

von Wettstein R (1891) Scrophulariaceae. In: Die Natürlichen Pflanzenfamilien, Vol. 4. (eds A Engler \& K Prantl), 39-107. W. Engelmann, Leipzig, Germany. 